\title{
Suicidal Tendency in Martin Sharp's Depression of Nick Hornby's A Long Way Down
}

\author{
${ }^{1}$ Universitas Negeri Surabaya \\ Surabaya, Indonesia \\ fdientara@gmail.com \\ ${ }^{2}$ Universitas Negeri Surabaya \\ Surabaya, Indonesia \\ mamikwedawati@unesa.ac.id \\ ${ }^{3}$ UIN Sunan Ampel Surabaya \\ Surabaya, Indonesia \\ dhika.hai@gmail.com
}

Fahrurozy Ahmad Dientara ${ }^{1}$, Mamik Tri Wedawati ${ }^{2}$, and Muhammad Dhika Arif Rizqan ${ }^{3}$

\begin{abstract}
Suicidal ideation, also known as suicidal thoughts or suicidal tendencies, concerns one thought about suicide. A Long Way Down tells about four characters that need to be done on New Year's Eve at the Topper's House building, London. The focus of this study on one of the main characters in this novel named Martin Sharp. There are two questions in this study: How is the tendency of self-murder to be described in A Long Way Down? and What is the socio-cultural influence on suicidal tendency of Martin Sharp? The study aims to reflect the desire to kill themselves in novel works and what socio-cultural things that causes of the desire to kill themselves. The core data from this study were taken from soliloquy and the thought narrative of Martin Sharp. Data were analyzed using Emile Durkheim's theory of suicide types. The results of this study showed that there are those who prove themselves from Martin Sharp causing by three socio-cultural issues that surround it: his status as a man who is middle-aged in England, family relations, and social pressure. The thought of self-killing from Martin Sharp was categorized as egoistic self-murder.
\end{abstract}

Index Terms — suicidal tendency, suicidal ideation, egoistic suicide.

\section{INTRODUCTION}

Mood disorder covered many emotional disorders that make an individual can't function properly, from sorrow from depression to unrealistic euphoria and irritability of mania. Frankly, everyone in this world ever felt this kind of sadness feeling varied from mild to a chronic one. In this Nick Hornby latest work titled "A Long Way Down" he recorded this adventure novel of everyday life which is growing darker and darker in his work from football story in Fever Pitch, to love life confession of record store worker on High Fidelity and finally to this novel. There are so many tendencies, suicidal tendencies covering literally and disguisedly the whole atmosphere of the novel. There are so much uncertain and uncomfortable moods of sociological-related issues that interesting to be discussed.

Freud (1920) stated that suicide is an outlet of a repressed wish to vanish a lost love object, and one of a revenge act. "A Long Way Down" is a novel that published in 2005, playing around in suicide, angst and depression theme. Set on the London in uncertain time (most probably in the year 2000s) the story is beginning by the four desperate people that their first intention is to suicide in solitude but accidentally bumped one to other and canceled the darkest plan of their life, deciding to protect each other from doing suicide. The next story is like they build their previous broken life together which is must be helpless, repairing the breaks and strengthen each other through "adventure" and "journey".

The modern social and psychological state of mind of thousands of millennial world citizens perfectly depicted from the way story built through first-person narrative. This four characters ideation pictured perfectly a modern 
complicated life as Hawton, et al (1997) data summary explained and mentioned problems that triggered a suicide: interpersonal relationships, employment problems, difficulties with children and financial problems while in the adolescents it mostly concerns its emotional lability.

Nick Hornby (born as Nicholas Peter John Hornby) is an English-born writer, essayist, screenwriter and lyricist that started his literary works in the mid Nineties with his notable works "High Fidelity" that well-known recognized and its movie adaptation starred by John Cusack catapulted his name. Nick Hornby was born in Redhill, Surrey. The chairman of London and Continental Railways Sir Derek Peter Hornby was his father and Margaret Audrey Hornby was his mother. He went to Maidenhead Grammar School and took a college at Jesus College, Cambridge, where he studied English. Later on, when he was eleven his parents divorced.

His first published book in 1992 is a miscellany of essays about American Writers titled Contemporary American Fiction. The next book that leads to his recognition on authorship world is Fever Pitch, a memoir and autobiographical story of football team Arsenal FC and his adoration towards it, surprisingly awarded as Sports Book of the Year in 1992 by William Hill until the books turned into a movie in 1997 in the UK and 2005 in USA. His third book and first novel work are called High Fidelity, published in 1995 and received a favorable reaction as it tells a story about neurotics record collector and record store owner and his failing relationship. He is notably known writing articles and essays on Sunday Times, Time Out and the Times Literary Supplement, as he also writes music reviews in New Yorker. There are up to 7 fiction works of Hornby's, High Fidelity (2005b), About a Boy (2005a), How to Be Good (2002), A Long Way Down (2005c), Slam (2009b), Juliet, Naked (2009a), and his latest Funny Girl (Hornby, 2015). His novel A Long Way Down shortlisted on 2005 Whitbread Novel Award.

Based on the paragraph above, it is known that Hornby's life and works shadowed by 90 s and Millennials' era, well-educated man, and the mostly main theme of his theme ranging in "urban" and "middle-class". It giving an impression that if someone wants to discuss his works should have done it in newer literary/cultural theory that suited with his works or the universal one that flexibly fitted in most works.

Suicide is a complex problem where there is no one certain motive or one certain reason. It resulted from complex interaction of biology, genetic, psychology, social, culture and environment factors. It is difficult to explain why some people deciding to end their own life while other people might don't want to do it even they caught in similar problem or even more complex problems.

An advanced model of social theory of suicide developed by Durkheim (1951) that familiarize three types of suicide: anomic, altruistic and egoistic. Anomic suicide, as stated by Durkheim, happened when social structure that takes place where the individual lives cannot give enough support for them, and caused a weakening sense of belonging - a state known as anomie. High levels of anomie could happen when there is both societal and personal change, including economic stress, immigration and social disturbance. Altruistic suicide develops when an individual purposely sacrifices themselves for the concern of others or the community. Last, egoistic suicide happens when the norms of society governed less, who are loners or outsiders in a more permanent state of alienation than those who commit anomic suicide.

The existential thought of philosophers like Camus (1955, pp. 3-8, 21-37) makes it obvious that confronted with the absurdity of this life, man can prefer for physical suicide or intellectual/philosophical suicide in the form of a passive embrace of religion or hope. Those who choose to end their lives are, more or less, subtly express that they are in control over their lives. Julia Kristeva argues that suicide is equal to confirming that God's will is less strong than a man, that the human ego has "supreme power". For Camus, suicide is "pleading that life is too much for you or that you do not understand it". It is also often "a solution to the absurd" as one kills "oneself because life is not worth living". In this case, suicide is a solution to an existential dilemma.

This study intention is to investigate the depiction of Martin Sharp's suicide tendencies in A Long Way Down written by Nick Hornby, along with its socio-cultural background. Two main problems are going to be discussed in this study: How are Martin Sharp's suicidal tendencies depicted in Nick Hornby's A Long Way Down? and How is socio-cultural background from Martin Sharp's suicidal? To avoid excessive discussion, the limitation is of the study is only focused on the Martin Sharp as the main object of this study, the other characters also playing part but limited to give additional information about Martin Sharp's suicide ideation.

\section{METHOD}

This study investigates the novel Nick Hornby's A Long Way Down, the main data to analyze come from the characters' attitude, action, and expression that showing the suicide ideation. The form of theoretical framework in the following chapter contains Durkheim's (1951) suicide theory applied to reveal Martin Sharp's suicidal tendencies. Then to answer the second statement of the problems, it is best to explain to socio cultural behind it, like the setting. This concept used in further analysis to reveal the suicidal, which reflected through Martin Sharp's story.

Extensive reading is required as a first step to understand the data and to finish the analysis. The next step is intensive reading to collect data from characters' attitude, expression, thought, and action which representing the general description of Martin Sharp and the idea of suicide. Throughout the intensive reading, the observation by classifying of thought and description is must be done to fulfill the precise and filtered data which contains the mentioned idea previously.

The filtered data that compiled from what mentioned in data collection, are analyzed by using the declared 
concepts; suicide and an example of depression regression. First step of analyzing will be revealing the depiction of suicide tendencies throughout the characterization of Martin Sharp. Second, to answer the last statement of the problems, to reveal how Martin Sharp's suicidal tendencies do reflect depression regression. Approaching the problems distinguish the type of suicide into four (egoistic, altruistic, anomic, and fatalistic).

\section{RESULT AND DISCUSSION}

\section{A. Depiction of Suicidal Tendencies in the Story}

Klonsky, May, and Saffer (2016) stated that suicidal ideation or thoughts are thinking, considering or planning about suicide, whether it's just momentary thoughts, profound thoughts until extensive planning. Suicidal ideation could happen when a person feels they are no longer fit to face an overwhelming situation. This could originate from financial issue, fate of a significant others, a broken relationship, or a devastating or weakening illness. The most common circumstances or life events that might cause suicidal thoughts are grief, sexual abuse, financial problems, remorse, rejection, a relationship breakup, and unemployment (Nordqvist, 2018).

The title itself, A Long Way Down reflect a nuance that something depressing, a never-ending deprecating moment that keeps on going down. The word "down" itself based on Merriam-Webster dictionary means more than one thing, the highlighted meanings of word "down" are: "to a lesser degree, level, or rate'; 'to or toward a lower position in a series'; 'to or in a lower or worse condition or status'. Clearly, this represent depreciating mood of the novel.

Martin Sharp, whose appeared first both in the story and in the movie, somewhat became the more protagonist character compared to the other three, not because he showed up first both in the movie adaptation or the book, but he seems to be the 'father' of this 'nihilistic family', if these 4 characters could be said as so. Moreover, Martin Sharp is somehow recognized by the reader as the most privileged character among those 4 characters. It seen from his status as a celebrity, mature enough from age, and was a man in a complete family until the adultery scandal hit him.

Martin was a celebrity with a perfect life that consisted of his wife and two daughters. However, his life is ruined as he is caught sleeping with a 15-year-old. As he is released from the prison, he realizes that he got fired from the show "Rise and Shine with Penny and Martin" and his wife has divorced him. As his popularity gets stripped from him he takes up a job as a T.V show host of a low popularity cable channel called as 'FeetUp!TV'. Martin then starts an affair with his previous co hostess Penny. He arrives at Toppers Tower to commit suicide as he believes that he has no more dignity and pride as people constantly call him names for his mistake of sleeping with a 15-year-old.

"Can I explain why I wanted to jump off the top of a tower-block? Of course, I can explain why I wanted to jump off the top of a tower-block. I'm not a bloody idiot.
I can explain it because it wasn't inexplicable: it was a logical decision, the product of proper thought. It wasn't even a very serious thought, either. I don't mean it was whimsical - I just meant that it wasn't terribly complicated or agonized" (Hornby, 2005c, p. 3)

Martin open the story with his soliloquy, a personal confession about suicidal ideation that takes place on the roof of Topper' House, a London destination famous as the last stop for those ready to end their lives. It cumulating in his mind and he got quite extensive thought about his suicide plan by jumping from the top of a tower block and

“...spent the previous couple of months looking up suicide inquests on the Internet." (Hornby, 2005c, p. 8)

In the next sentence he even explained detailed analogy between taking suicide and job offering.

"Put it this way: say you were, I don't know, an assistant bank manager, in Guildford. And you'd been thinking of emigrating, and then you were offered the job of managing a bank in Sydney. Well, even though it's a pretty straightforward decision, you'd still have to think for a bit, wouldn't you?"

Martin stated that it's a straight-forward decision, and implied that even it's a difficult decision to make and every decision have each good side and bad side, he said that the cons side is just gravel in his shoes.

"Well, that was me. There simply weren't enough regrets, and lots and lots of reasons to jump.' (Hornby, 2005c, p. 3)

Later on Martin express a statement that suicide is an escape, an escape from his self (Baumeister, 1990) by saying "Suicide was my Sydney", but it also subtly implied that he wants to go somewhere. A place or a condition where he doesn't feel any pain, because his main purpose, the real intentions, is not about end his life, but rather to stop the great amount of tormenting thoughts and feelings about himself and his lives (Leary, 2018).

"Bad thing upon bad thing upon bad thing until you can't take any more, and then it's off to the nearest multi-storey car park in the family hatchback with a length of rubber tubing." (Hornby, 2005c, p. 8).

The ex-presenter said 'bad things' three times, indicating that it is not just a single reason that making some people thought about suicide. Events of life are one of the biggest factors that caused suicidal tendencies/ideation (Fergusson, Woodward, \& Horwood, 2000). Life events that adults and children face can be dissimilar and for this reason, the list of events that increase risk can vary in adults and children. There are lots and lots of factors that push people over the edge; none of these factors are likely to make you feel anything but "..fucking miserable", as he added the previous statement.

Martin going gore and horrible as he was

“...looking a hundred feet down at a concrete walkway and wondering whether he'd hear the noise that his bones made when they shattered into tiny pieces." (Hornby, 2005c, p. 10).

His suicide ideation is going dreadful as some people might not be brave enough to wondering how their body affected when they are committing suicide. It suits with the 
characteristic of suicide ideation that extensive thoughts of suicide occurred in the perpetrator's mind because it reveals kind of suicide thoughts imagining the sense and feel of doing suicide.

Once again, the series of misfortune events, insistently misery, or a train car series full of adversity become a reason why Martin decided that "Suicide was my Sydney". It struck him over and over as he said

"Wanting to kill myself was an appropriate and reasonable response to a whole series of unfortunate events that had rendered life unlivable." ( Hornby, 2005c, p. 10).

Suicide ideation is often characterized by: hopeless, like there is no point in living; miserable and overwhelmed by negative thoughts; unbearable pain that seems endless; useless, unwanted or undesired by others; desperate, as if there are no any other chances left in the world (March, 2016). On this quotation below, it shows that Martin had at least 2 characteristics of suicidal ideation.

"On New Year's Eve, it felt as though I'd be saying goodbye to a dim form of consciousness and a semifunctioning digestive system - all the indications of a life, certainly, but none of the content. I didn't even feel sad, particularly. I just felt very stupid, and very angry."

When he said he wants to "saying goodbye to life" it means that he desperate and have no other choice as mentioned on the characteristics above. Then he said "I just felt very stupid, and very angry" it reflects that he is tearful and overwhelmed by negative thoughts. There we found a representation of suicidal tendencies or ideation.

Martin was bringing a ladder to help him jump off of the roof. But before he jump off he suddenly "...felt this thump on my back, and I turned round and grabbed the railings behind me, and I started yelling." (․ Hornby, 2005c, p. 17)

Because somebody wants to lend his ladder, whose named Maureen, the next character in the story that got the same intention to do suicide in the same place and the same time with Martin. Long story short, Martin was doing his preparation to jump off but suddenly he postponed the jump as he feel not quite ready as he said "I'll give you a shout on the way down.' I laughed, but she didn't." to Maureen. It's one example of self-deprecating jokes that happened in depressive scene. This is kind of self-enhancing and affiliating humor that have correlation to depressive symptoms' (Dyck \& Holtzman, 2013; Tucker et al., 2013) which is positively correlated to the triggering factor of suicidal ideation.

Another example of suicidal ideation trait like depression that covered with self-enhancing and affiliating humor was depicted here

"'Oi! Do you want to swap places? See how you get on?' And I laughed again." (Hornby, 2005c, p. 17).

Clearly there is a depiction of depression through is dark jokes uttered by him that subtly iterate his wish of death. He both subconsciously and consciously wanted to end his life by jumping off of the rooftop and once again correlated to depressive symptoms that correlated to the triggering factors of suicidal ideation.

A journal titled Men and Suicide: Why it's a Social Issue (Hatch, 2012) encapsulated that losing pride is one of triggering factors that make men in middle-aged having suicidal thoughts or attempting suicide just as depicted in the quotation above of Martin having a confession in his mind about "Why is it easier to like leap into the void than to face up to what you've done?" (Hornby, 2005c, p. 41), as $\mathrm{JJ}$ the young man asked the question to Martin.

"I was practicing what I preached. I hadn't been able to keep my thing in my trousers, so now I had to jump. I was a slave to my own logic. That was the price you had to pay." (Hornby, 2005c, p. 42)

That kind of thought and act is similar to what samurai (member of the Japanese warrior caste (Encyclopedia Britannica, Samurai)) do when they got disgrace or losing their honor. It is called seppuku or hara-kiri in popular culture. Martin told previously that he ever wrote an article where the adultery perpetrator or philanderer should have punished with

"..resignations and chemical castrations and prison sentences and public humiliations and penances of every kind."(Hornby, 2005c, p. 42),

so he feel guilty and think that he should pay for the word that he had been wrote.

Another reason that leads Martin to thought of kill himself is humiliation. It is depicted a few sentence after his confession above. He stated that

"'It's not just that, anyway. It's the public thing. The humiliation.." (Hornby, 2005c, p. 42).

Humiliation is a triggering factor that ignites a chain reaction to the next effect, the loosening integration. Shneidman (1993) stated in his book Suicide as psychache: A clinical approach to self-destructive behavior that damaged self-image rises feelings of avoidance, shame, defeat, and humiliation is leading to psychache or frustrated need. Humiliation is one triggering factor of suicide based on Shneidman statement, and later on the story, his detached relationship with his wife, kids, works, as TV presenter and fame categorized by Durkheim (1951) as Egoistic suicide. The type of suicide that is caused by one social integration's weakened. It occurs in a society where there is great sense of individualism and weak level social integration. Egoistic suicide is committed by people that support by membership loosening up in a unified social group. Detachment from society results in detachment from life because society gives meaning to life.

As the story goes, Martin cancels his suicide as he and the other three characters joined up to search the boy that makes Jess impulsively jump off the roof. Then on his dialogue part he confesses something like

"I'll have you know that I scored very highly on Aaron

T. Beck's Suicide Intent Scale." (56).

The suicide intent scale was developed by Aaron T. Beck and his colleagues at the University of Pennsylvania in 1974 for use with patients who attempt suicide but survive. There is no doubt that Martin Sharp ever had suicidal thought in his mind, and people tend to seek justification 
about their self, it could be personality test, horoscope, or suicide intent scale in Martin's case.

"Yes, suicide had been contemplated for more than three hours prior to the attempt" (56)

as Martin add to their previous confession. Suicide thought no matter how long it is taken to think about it is a suicidal thought. There is no any academic journal or detailed examination yet about how much time should take to be considered as suicidal thought. Most literature and article just mentioned it is spread between fleeting thought to detailed plan (Nordqvist, 2018)

It continued on the next sentence as he confesses

"Yes, I was certain of death even if I received medical attention: it's fifteen storeys high, Toppers' House, and they reckon that anything over ten will do it for you pretty well every time" (Hornby, 2005c, p. 57).

This is kind of detailed plan as mentioned above. Calculating on how tall the building to make one die of jumping off over the roof is kind of detailed plan. Just like he did an

"..active preparation for the attempt: ladder, wirecutters and so on." (Hornby, 2005c, p. 57).

He continued his suicidal confession, depreciated aspiration about life as he stated here

"Not one of us descended those stairs having come to the conclusion that life was a beautiful and precious thing.."(57).

On one mind that's got suicidal thoughts circling inside their head it is just like a dust storm where we can't see anything except the dust and the rumble that filled our ear tube. It is just uncertainty around and we can't see the clear path of our way. Martin assuming that life is not a beautiful and precious thing is really a natural thing for someone who got suicidal thoughts inside their head.

This is the ironic fact that found on the novel. For them, whose suicidal ideation lodged inside their head, it might be true that

"..we were slightly more miserable on the way down than on the way up, because the only solution we had found for our various predicaments was not available to us.." (Hornby, 2005c, p. 57).

It is simply said that they think they are just equally miserable whether they did suicide or not because, referring to his previous sentence that life is not a beautiful and precious thing anymore (57).

In the previous discussion, it is revealing an analysis that suicide is an attempt to escape from the self, to get rid of the responsibility of being a human. It is once again stated on his confession.

"And there had been a sort of weird nervous excitement up on the roof; for a couple of hours we had been living in a sort of independent state, where street-level laws no longer applied. Even though our problems had driven us up there, it was as if they had somehow .... been unable to climb the stairs. And now we had to go back down and face them again. But it didn't feel like we had any choice.." (Hornby, 2005c, p. 57).

Noticing on the part "...for a couple hours we had been living in a sort of independent state...", it is a perfect depiction and proving that suicide is a escape from the aversive self-awareness (Baumeister, 1990). Suicide will be seen as a final step within the effort to flee from self and world. The "independent state" that quoted above is a sign of one wants to lose any affairs with human responsibility and "..where the street-level laws no longer applied." (57). It is a limbo in other word.

Then to cap off his confession he express that "..the one thing was enough to make us feel that there wasn't anything else - not money, or class, or education, or age, or cultural interests - that was worth a damn..." sign of self deprecative traits that part of suicidal ideation (Garlow et al., 2008). Everything that in their life that somehow precious in their life is not worthy anymore because a series of misadventure things and a lot of bitterness in his life that leads Martin Sharp climbing up the roof of Topper's House on the New Year's Eve to end his life.

The socio-cultural background of Martin Sharp's suicidal ideation is playing a big role. Lack of collective unconsciousness leads to weakened social integration as Emile Durkheim state on his seminal books Le Suicide (1951). As it depicted in the story, Martin's most close interaction with his social unit that frequently recited and on his suicidal confession throughout the story is his family. One wife and two kids that divorce him and keep away his kids from him since his sex scandal with underage make Martin's social integration with his least social unit weakened, that direct to his suicidal attempt.

In Le Suicide, it clearly stated about the relationship between social integration toward suicidal tendencies. Durkheim sees suicide as individual action that backgrounded by social factors. Durkheim denied the existence of series of assumption that suicide caused by mental disease, imitation, climate, alcoholism, poverty and influence of a certain race that have suicidal.

The suicide rates differ between countries (Wasserman et al., 2012) and it is believed that every country had their own problem facing this suicide and it is mostly rooted from their environment, folklore, legislation, beliefs and certainly the social cultural aspect surrounding the country.

\section{B. Socio-Cultural Background of Martin Sharp's Suicidal Ideation}

Lack of collective unconsciousness leads to weakened social integration as Emile Durkheim state on his seminal books Le Suicide (1951). As it depicted in the story, Martin's most close interaction with his social unit that frequently recited and on his suicidal confession throughout the story is his family. One wife and two kids that divorce him and keep away his kids from him since his sex scandal with underage make Martin's social integration with his least social unit weakened, that direct to his suicidal attempt.

In Le Suicide, it clearly stated about the relationship between social integration toward suicidal tendencies. Durkheim sees suicide as individual action that backgrounded by social factors. Durkheim denied the existence of series of assumption that suicide caused by 
mental disease, imitation, climate, alcoholism, poverty and influence of a certain race that have suicidal.

The suicide rates differ between countries (Wasserman, et al., 2012) and it is believed that every country had their own problem facing this suicide and it is mostly rooted from their environment, folklore, legislation, beliefs and certainly the social cultural aspect surrounding the country.

\section{The Relation between Martin's Socio-Cultural Aspects and His Suicidal Ideation}

Martin Sharp in the story is depicted as a middle-aged man, with British nationality, used to have a family, and previously had a wonderful occupation as a famous TV presenter. However, since the scandal that happened to him everything is change. He got suicidal ideation and he attempted suicide on New Year's Eve on the rooftop of Topper's House, a notable building in London to commit suicide, as depicted in the story. The suicide phenomenon that told on the story is not just a slice of life placed in the story, or a writer's attempt to dramatize a story, or just a symbolization of a bigger idea that writer try to communicate to the reader, it can be also examined and seen as a social phenomenon that based on close reading on the story we can discover how is the social-cultural aspects surrounding Martin Sharp that possibly caused his suicidal ideation. The most simple and obvious socio-cultural background of Martin Sharp that depicted on the story is: Personal background as middle-aged man in Britain, Family, and Society Pressure. Those aspects will be explained below.

Suicide in middle-age men become a concern in Great Britain that Samaritans released a report in 2012 about suicide and men in Britain. According to the report, there are at least two reasons of why men do suicide and suit with Martin's background condition. First, it said there that power, control, and invincibility is set as a 'gold standard' which men compare themselves to. Suicidal thoughts could possibly come when they feel a sense of disgrace and believe they are not fulfilling this degree. It is perfectly correlated with Martin situation where he loses his highlevel job as breakfast TV presenter and so too his jet-set life. The money, the privilege, and the honor that he once had as famous people in Britain all vanished as the scandal hit him. Suicidal ideation will be likely come when Martin in those social condition, the shame come as Martin believe he is not meeting the 'gold standard' as mentioned above.

The dependence of Martin Sharp to their family is one of a big reason why he became such vulnerable man. It is frequently on the story how describing Cindy his former wife, how he missed his two daughters that he is not allowed to see and his life and his relation to his family before the scandal hit him. According to the report, lack of emotional support from a female partner plays a big role to suicide ideation in Britain men. The next general reason mentioned on the report is female partner exaggeratedly needed by men in mid-life for emotional support. But the fact is men got less chance to have one steady pair and more possibility to live alone, leave men lose their social or emotional skills to return. It perfectly correlated with Martin suicide ideation.

The next socio-cultural aspect that affects suicidal ideation in Martin is society pressure towards him in the form of shame and bully. A man who is in his lowest mental condition where no emotional support available and got no any 'power' behind him is tend to be vulnerable against bully of society. It is depicted in the story that newspaper and mass media blow up his scandal, people talk about him, even Jess ex-boyfriend Chas recognized Martin as "...that wanker off the telly. Martin Thing." (Hornby, 2005 c, p. 44) on the scene where the four characters chasing Chas. It possibly that the scandal nationally spread in the story until common people simply recognized Martin as an adulterer. A bully from society contributing big part to Martin's shame and lead to his suicidal attempt. Martin's case could be a little picture of our society nowadays; people tend to bully someone who is in trouble rather than giving support. Martin condition could be saved if only he got support from his family and accept his circumstances. Thus, suicide is a social phenomenon and socio-cultural aspects towards one who ever thought, attempted, and committed suicide greatly affects them.

\section{CONCLUSION}

All in all, the suicide can be happened when social integration loosened on someone. This is the reason why the socio-cultural factors become the major theme of the story. Martin's case is where he attempted an egoistic suicide; his social integration is loosened up as he is estranged from his previous life. He is detached from his wife, daughters and his jet set life because a scandal and that is a consequence that he should face. Actually, Nick Hornby wants to deliver the death as the way to see live in another perspective in A Long Way Down. However, he does not illustrate the idea obviously. He portrays the four different characters to end their life to start his novel. It turns out that they face the life in a new perspective since the attempted suicide. Finally, suicide is an ancient phenomenon that still happened today but we have to be aware of our healthiness and aware of our environment, give support to those who needed the most. Life is a precious thing gifted from God.

not submit a reworked version of a paper you have submitted or published elsewhere. Do not publish "preliminary" data or results. The submitting author is responsible for obtaining agreement of all coauthors and any consent required from sponsors before submitting a paper. IRSC UNUD JOURNALS strongly discourage courtesy authorship. It is the obligation of the authors to cite relevant prior work.

At least two reviews are required for every paper submitted. For conference-related papers, the decision to accept or reject a paper is made by the editors and publications committee; the recommendations of the referees are advisory only. Undecipherable English is a 
valid reason for rejection. Authors of rejected papers may revise and resubmit them to the IRCS UNUD as regular papers, whereupon they will be reviewed by two new referees.

\section{REFERENCES}

[1]Baumeister, R. F. (1990). Suicide as escape from self. Psychological review, 97(1), 90.

[2]Camus, A. (1955). The myth of Sisyphus and other essays (J. O’Brien, Trans.). New York: Vintage International.

[3]Durkheim, E. (1951). Suicide: a study in sociology [1897]. Translated by JA Spaulding and G. Simpson (Glencoe, Illinois: The Free Press, 1951).

[4]Dyck, K. T., \& Holtzman, S. (2013). Understanding humor styles and well-being: The importance of social relationships and gender. Personality and Individual Differences, 55(1), 53-58.

[5]Fergusson, D. M., Woodward, L. J., \& Horwood, L. J. (2000). Risk factors and life processes associated with the onset of suicidal behaviour during adolescence and early adulthood. Psychological medicine, 30(1), 23-39.

[6]Freud, S. (1920). A general introduction to psychoanalysis: Boni and Liveright.

[7]Garlow, S. J., Rosenberg, J., Moore, J. D., Haas, A. P., Koestner, B., Hendin, H., \& Nemeroff, C. B. (2008). Depression, desperation, and suicidal ideation in college students: results from the American Foundation for Suicide Prevention College Screening Project at Emory University. Depression and Anxiety, 25(6), 482-488.

[8]Hatch, S. (2012). Men and Suicide - Why it's a social issue Retrieved May 4th, 2019, from https://www.bevanfoundation.org/commentary/men-and-suicidewhy-its-a-social-issue/

[9]Hawton, K., Fagg, J., Simkin, S., Bale, E., \& Bond, A. (1997). Trends in deliberate self-harm in Oxford, 1985-1995: Implications for clinical services and the prevention of suicide. The British Journal of Psychiatry, 171(6), 556-560.

[10] Hornby, N. (2002). How to be Good: Penguin.

[11] Hornby, N. (2005a). About a boy: Penguin UK.

[12] Hornby, N. (2005b). High fidelity: Penguin UK.

[13] Hornby, N. (2005c). A Long Way Down: the international bestseller: Penguin UK.

[14] Hornby, N. (2009a). Juliet, naked: Penguin UK.

[15] Hornby, N. (2009b). Slam: Ernst Klett Sprachen.

[16] Hornby, N. (2015). Funny girl: Stock.

[17] Klonsky, E. D., May, A. M., \& Saffer, B. Y. (2016). Suicide, suicide attempts, and suicidal ideation. Annual review of clinical psychology, $12,307-330$.

[18] Leary, M. (2018). Suicide as an Escape from the Self Retrieved April 30th, 2019, from https://www.psychologytoday.com/intl/blog/toward-less-egoicworld/201806/suicide-escape-the-self

[19] March, C. (2016). How to cope with suicidal feelings Retrieved May 21st, 2019, from https://www.mind.org.uk/media/4657603/how-tocope-with-suicidal-feelings_2016.pdf

[20] Nordqvist, C. (2018). What are suicidal thoughts? Retrieved April 29th, 2019, from https://www.medicalnewstoday.com/kc/suicidalthoughts-ideation-193026

[21] Shneidman, E. S. (1993). Suicide as psychache: A clinical approach to self-destructive behavior: Jason Aronson.

[22] Tucker, R. P., Judah, M. R., O’Keefe, V. M., Mills, A. C., Lechner, W. V., Davidson, C. L., . . . Wingate, L. R. (2013). Humor styles impact the relationship between symptoms of social anxiety and depression. Personality and Individual Differences, 55(7), 823-827.

[23] Wasserman, D., Rihmer, Z., Rujescu, D., Sarchiapone, M., Sokolowski, M., Titelman, D., . . Carli, V. (2012). The European Psychiatric Association (EPA) guidance on suicide treatment and prevention. European psychiatry, 27(2), 129-141.G. O. Young, "Synthetic structure of industrial plastics (Book style with paper title and editor)," in Plastics, 2nd ed. vol. 3, J. Peters, Ed. New York: McGraw-Hill, 1964, pp. 15-64. 